\title{
Dung beetles (Coleoptera: Scarabaeoidea) population patterns in three environments in the Midwest of Brazil
}

\author{
Manoel Araécio Uchoa ${ }^{\bowtie}$ \& Marino Miloca Rodrigues ${ }^{2}$
}

1. Universidade Federal da Grande Dourados. 2. Centro de Controle de Zoonoses de Dourados.

EntomoBrasilis 12 (1): 19-26 (2019)

\begin{abstract}
Scarabaeids are economically very important due to their provision of several environmental services, in particular to cattle rearing, because they are highly active in the decomposition of cattle feces in pasture environments. The objectives of this research were to evaluate the season of dung beetle occurrence, and the effect of weather on their abundance and species richness in different environments. A total of 44,355 adults were captured: 105 samples in each of three different environments (agroecosystem, pasture and native forest), adding 315 samples for two consecutive years (November 2005 to November 2007). Fifty-three species were found in that three environments, being 51 of Scarabaeidae, including two subspecies of Dichotomius, and two of Hybosoridae: Coilodes humeralis (Mannerheim) and Coilodes sp.1. We verified a correlation between temperature and rainfall and the occurrence of Scarabaeidae species associated with bovine feces. The species with highest population levels were: Labarrus pseudolividus Balthasar in the pasture, and Ataenius platensis (Blanchard) in both: agroecosystem and native semi-deciduous forest. There was a positive correlation between higher temperature and rainfall with an increase in the abundance of adult dung beetles in the environments. The number of adults caught and species richness of dung beetles was significantly greater in the pasture when temperature and rainfall were higher. The combined analysis of the three environments showed that from Oct to Dec, when temperature and precipitation were highest, there was a significant increase in the capture of dung beetles in the traps in comparison to the period from Apr to Jul (coldest season).
\end{abstract}

Keywords: Biodiversity; Coprophagous beetles; Environments; Neotropics; Seasonality.

\section{Padrões populacionais dos escaravelhos (Coleoptera: Scarabaeoidea) em três ambientes no Centro- Oeste do Brasil}

Resumo. Scarabeídeos são economicamente muito importantes devido à pestação de vários serviços ambientais, em especial para bovinocultura, porque atuam fortemente na decomposição de fezes bovinas em ambientes de pastagem. Os objetivos desta pesquisa foram avaliar as épocas de ocorrência das espécies de besouros "rola bosta" e o efeito do clima sobre a abundância e riqueza de suas espécies em diferentes ambientes. Um total de 44.355 adultos foram capturados: 105 amostras em cada um dos diferentes ambientes (agroecossistema, pastagem e floresta nativa), somando 315 amostras durante dois anos consecutivos (novembro de 2005 a novembro de 2007). Cinquenta e três espécies foram encontradas nos três ambientes durante dois anos de amostragem, 51 de Scarabaeidae (incluindo duas subespécies de Dichotomius) e duas espécies de Hybosoridae: Coilodes humeralis (Mannerheim) e Coilodes sp.1. Houve correlação entre a temperatura e as chuvas com as épocas de ocorrência das espécies Scarabaeidae associadas com fezes bovinas. As espécies com níveis populacionais mais elevados foram: Labarrus pseudolividus Balthasar na pastagem e Ataenius platensis (Blanchard) em ambos: agroecossistema e floresta nativa semidecídua. Existe uma correlação positiva entre temperaturas mais elevadas e chuvas com aumento na captura dos "rola bosta" em armadilhas. O número de adultos capturados e a riqueza em espécies dos "rola bosta" capturados foi significativamente superior quando a temperatura e a pluviosidade foram mais altas. A análise combinada dos três ambientes mostrou que de outubro a dezembro, quando a temperatura e a precipitação foram mais elevadas, houve um aumento significativo na captura destes besouros nas armadilhas em comparação com o período de abril a julho (estação mais fria).

Palavras-chave: Ambientes; Biodiversidade; Região Neotropical; Sazonalidade; "Rola-bosta".

carabaeids are economically very important due to their provision of several environmental services, in particular to livestock rearing, because of their strong impact on the decomposition of cattle feces in pasture environments (KolLER et al. 2007), cycling organic matter in nature, making substrates and nutrients available to the biota.

In Brazil, cattle production was very successful from the beginning. According to PRIMO (1992), cattle (Bos taurus L.;
Bovidae) was first introduced in São Vicente, São Paulo state in 1534, by Mr. Martim Afonso de Sousa, and his wife, Ana Pimentel, from Portugal and Spain. At least in part, the success of Brazilian cattle production could be attributed to the high natural diversity of dung beetles that occurs from north to south Brazil. Herein, when cattle arrived in 1534, dung beetles soon began to feed and breed in their fecal masses, because they already were evolutionarily adapted to living in feces of big native

\section{Edited by:}

William Costa Rodrigues

\section{Article History:}

Received: $10 . x i .2018$

Accepted: 16.iii.2019

\section{Corresponding author:}

Manoel Araécio Uchoa

७ $\underline{\text { uchoa.manoel@gmail.com }}$

(3ttp://orcid.org/0000-0001-5764-1421

\section{Funding agencies:}

4 CNPq-Conselho Nacional de Desenvolvimento Científico e Tecnológico, Fundação de Apoio ao Desenvolvimento do Ensino, Ciência e Tecnologia do Estado de Mato Grosso do Sul (FUNDECT), and Coordenação de Aperfeiçoamento de Pessoal de Nivel Superior (CAPES). 
mammals, such as: tapir, Tapirus terrestris (L.) (Tapiridae); capybara, Hydrochoerus hydrochaeris (L.) (Caviidae); wild hogs or 'queixada' Tayassu pecari (Link), and 'cateto,' Pecari tajacu (L.) (Tayassuidae); multiple species of some Cervidae genera: Blastocerus spp., Mazama spp., Odocoileus spp., and Ozotoceros spp., and other ungulates. On other hand, cattle was for the first time introduced in Australia by 1778, but in contrast to Brazil, within a few years ranchers faced problems due to bovine excreta accumulation. In Australia, due to a lack of efficient decomposers, year by year the areas available for cattle pastures decreased. Australian entomologists discovered that the problem was due to the fact that native dung beetle species from there were not adapted to feed and breed in bovine fecal masses (Bornemissza 1976). Prior to the introduction of bovines, the largest native mammals were kangaroos, Macropus (Macropodidae), which are phylogenetically distant from the genus Bos L. (Bovidae). The Australian problem was solved with the introduction of Scarabaeidae species that feed and breed in bovine feces, already established in Hawaii (USA), but native to Africa and Europe (BorNemissza 1976; Losey \& VAUGHAN 2006).

Several factors have been hypothesized to explain variations in the abundance of dung beetles, including weather, source of food, and nesting sites (Howden \& NeALis 1975; Gaston \& Chown 1999). Discover which factors are positively or negatively affecting animal, plant, and microorganism populations, is a central issue in ecology. According to Nichols et al. (2007), more than one factor may be simultaneously acting positively or negatively on populations of Scarabaeidae in their natural habitats.

In the tropics there are variations in dung beetle populations, depending on the degree of modification of the environment, the type of forest (intact or fragmented), the mode of land use, and weather (NicHoLs et al. 2007). The weather plays an important role in the seasons of adult dung beetle occurrence (HALFFTER et al. 1992; RONQUI \& LOPES 2006). There is evidence that higher temperatures and rainfall events contribute positively to the abundance of dung beetle populations (Koller et al. 2007; Nichols et al. 2007; Silva et al. 2007).

The modification and fragmentation of environments are the most common landscape patterns found worldwide in ecosystems with anthropogenic activities. In addition to the direct changes on the landscape, alter the local microclimate (Nichols et al. 2007). Knowledge of the population dynamics of dung beetles communities is very useful in the development of strategies for their conservation, to employ them as indicators of environmental degradation, and for their use in biological control programs against pestiferous invertebrates (e.g., nematodes and insects) that cause economic damage in agriculture and pasture environments.

Our hypothesis was that a higher species richness of dung beetles occurs in native forest in comparison with areas occupied by agriculture and pasture. In this context, the objectives of this research were: to evaluate the seasons of dung beetle species occurrence in three different environments (i.e., pasture, native semi-deciduous forest, and agroecosystem), and to determine the influence of temperature and rainfall on the species richness and abundance of Scarabaeoidea in these environments.

\section{MATERIAL AND METHODS}

Place of study. Samples of dung beetles were collected in three different ecosystems: a pasture with a monoculture of signal grass, Urochloa decumbens (Stapf) R.D. Webster (Poaceae); an agroecosystem with annual cultures of corn, Zea mays L. (Poaceae), in the fall (Mar to Jun), wheat (Triticum aestivum L.; Poaceae), in the winter (May to Aug), and soybean, Glycine $\max (\mathrm{L}$.$) Merr. (Fabaceae), in the summer (Dec to Feb), and a$ native semi-deciduous forest from the region of Dourados-MS, Midwest Brazil, from Nov 2005 to Nov 2007.
The environment with pasture $\left(21.9900000^{\circ} \mathrm{S}, 55 \cdot 3225556^{\circ} \mathrm{W}\right)$, was at $420 \mathrm{~m}$ altitude, and about $75 \mathrm{~km}$ from the Dourados downtown area, Mato Grosso do Sul state. This area (22 ha) is planted with $U$. decumbens, and is part of a total area of 4,800 hectares of rural settlement. The pasture is surrounded by a dense wooded 'cerrado' (i.e., Brazilian savannah) environment, and the soil is a dystrophic red latosoil of medium texture (Projeto Radambrasil 1982).

The agroecosystem $\left(22.1445000^{\circ} \mathrm{S}, 55.0260278^{\circ} \mathrm{W}\right)$ was at an altitude of $447 \mathrm{~m}$, and is $40 \mathrm{~km}$ from the Dourados downtown. It is $35 \mathrm{~km}$ away from the pasture area and $20 \mathrm{~km}$ away from the native semi-deciduous forest. In total 2,470 hectares is occupied annually with a soybean, corn, and wheat rotation. There are some spots with natural vegetation including: swamps, springs, small streams, and riparian vegetation. The phyto-ecological formation is similar to that of the pasture area, but with clay soil (Projeto Radambrasil 1982).

The native semi-deciduous forest $\left(22.9902500^{\circ} \mathrm{S}, 54.9156111^{\circ} \mathrm{W}\right)$ was at $434 \mathrm{~m}$ altitude. It is a natural heritage forest reserve of the old Fazenda Coqueiro, with 35 hectares, bordered by pastures, and around $20 \mathrm{~km}$ away from the Dourados downtown. Vegetation is of typical semi-deciduous forest type, and is considered a remnant of the Atlantic forest. The soil type is oxisol with clay. The weather is humid mesothermal (Cwa), according to Koppen's classification (ProJeto RADAMBRASIL 1982).

Sampling method. Samples were taken weekly, when the baits of the traps were exchanged. Exactly 315 samples were collected, comprised of 105 samples from each of the three environments. A set of three pitfall traps (i.e., one sample) per environment per week were baited with cattle dung according to the methodology by Koller et al. (2007). Traps were installed at a minimum distance of $200 \mathrm{~m}$ from each other, checked from 5 Nov 2005 to 3 Nov 2007, and weather data were obtained from Empresa Brasileira de Pesquisa Agropecuária, Centro de Pesquisas Agropecuária do Oeste (EMBRAPA-CPAO), Dourados-MS, Brazil.

The dung beetles caught were kept in vials with $70 \%$ ethanol and subsequently mounted on entomological pins, labeled and identified by Dr. S. Ide (Instituto Biológico de São Paulo). Voucher specimens were deposited in the Museu da Biodiversidade (MuBio), Faculdade de Ciências Biológicas e Ambientais (FCBA), Universidade Federal da Grande Dourados (UFGD), Dourados-MS, Brazil.

Data analysis. The seasons of occurrence of the predominant species were determined by taking in to account the monthly average of the number of individuals of each species caught in the three traps in each environment. For the calculations, the beetles captured weekly in the three traps from each environment were summed. We considered the species that were very abundant and very constant in each environment to be dominant.

To verify the influence of weather on the species sampled in the traps of each of the three ecosystems: pasture, agroecosystem, and native semi-deciduous forest, we applied the Pearson correlation index. To determine if means were significantly different we applied the non-parametric Mann-Whitney test for multiple comparisons (WHITTAKeR 1972) $(P<0.05)$. For the latter test, the average number of individuals (both males and females) captured by month in the traps in each ecosystem was calculated. Only those traps that captured at least one individual (herein named 'positive traps') in each environment were included in the analysis to verify whether there were significant differences between the environments. Finally, the results obtained from the non-parametric Mann-Whitney test (WHITTAKER 1972) were compared with the weather data. 


\section{RESULTS}

A total of 54 Scarabaeiodea (Coleoptera) taxa, including two subspecies of Dichotomius, were found in the three environments (i.e., pasture, agroecosystem, and native semi-deciduous forest), during 2 yrs with weekly sampling. The predominant species, in descending order, captured in the pasture were: Labarrus pseudolividus Balthasar (18.60\%), Genieridium bidens (Balthasar) (18.04\%), Ontherus appendiculatus Mannerheim (16.61\%), Trichillum externepunctatum Preudhomme de Borre
(9.38\%), and Ataenius platensis (Blanchard) (9.24\%). In the agroecosystem the predominant species were: $A$. platensis (73.91\%) and $A$. sculptilis Harold (12.10\%). In the native semideciduous forest the predominant species were: Eurysternus caribaeus (Herbst) (28.95\%), and Dichotomius carbonarius Mannerheim (21.00\%) (Table 1).

Twenty six species occurred in all three sampled environments, as follows: Agamopus viridis Boucomont, L. pseudolividus, A. platensis, Ateuchus pygidialis (Harold), Ateuchus

Table 1. Taxon richness and adult abundance of Scarabaeiodea (Coleoptera) in three different environments in Mato Grosso do Sul state, Midwest Brazil (Nov 2005 to Nov 2007).

\begin{tabular}{|c|c|c|c|}
\hline \multirow{2}{*}{ Taxa and Species Richness } & \multicolumn{3}{|c|}{ Abundance of Adult by Species in each Environment } \\
\hline & Native Forest & Pasture & Agroecosystem \\
\hline \multicolumn{4}{|l|}{ Scarabaeidae, Aphodinae } \\
\hline Aphodius (Nialus) nigritus Fabricius & 0 & 40 & 20 \\
\hline Ataenius platensis (Blanchard) & 478 & 1,215 & 19,122 \\
\hline Ataenius sculptilis Harold & 0 & 145 & 3,131 \\
\hline Blackburneus laxepunctatus (Schimidt) & 0 & 63 & 57 \\
\hline Labarrus pseudolividus Balthasar & 5 & 2,444 & 360 \\
\hline \multicolumn{4}{|l|}{ Scarabaeidae, Scarabaeinae } \\
\hline Agamopus viridis Boucomont & 5 & 605 & 9 \\
\hline Anomiopus virescens Westwood & 2 & o & 4 \\
\hline Ateuchus pygidialis (Harold) & 58 & 28 & 3 \\
\hline Ateuchus vividus Germar & 4 & 47 & 8 \\
\hline Ateuchus sp. 1 & 1 & 20 & 23 \\
\hline Ateuchus sp. 2 & 16 & 3 & o \\
\hline Canthidium (Canthidium) dispar Harold & 2 & o & 0 \\
\hline Canthidium (Canthidium) sulcatum (Perty) & o & o & 1 \\
\hline Canthidium (Canthidium) viride (Lucas) & 4 & 98 & 170 \\
\hline Canthidium (Eucanthidium) sp.2 & 5 & o & o \\
\hline Canthidium sp. 1 & 3 & 12 & 6 \\
\hline Canthidium sp. 2 & 5 & o & 1 \\
\hline Canthon (Francmonrosia) dives Harold & 0 & 3 & 233 \\
\hline Canthon laminatus Balthasar 1939 & 1 & 1 & 67 \\
\hline Canthon (Canthon) virens chalybaeus Blanchard & 3 & o & o \\
\hline Canthon (Glaphyrocanthon) oliverioi (Pereira \& Martínez) & 16 & o & o \\
\hline Canthon quinquemaculatus Castelnau & 32 & o & o \\
\hline Canthon (Canthon) sp. 1 & 1 & o & 1 \\
\hline Canthon (Canthon) sp. 2 & o & 4 & o \\
\hline Coprophanaeus jasius (Olivier) & 281 & 3 & 8 \\
\hline Coprophanaeus spitzi (Pessoa) & 2 & 2 & 7 \\
\hline Coprophanaeus (Metallophanaeus) sp.1 & o & 1 & 28 \\
\hline Deltochilum (Deltohyboma) aspericolle Bates & 430 & 11 & 6 \\
\hline Deltochilum (Hybomidium) icarus (Olivier) & o & o & 2 \\
\hline Dichotomius bos (Blanchard) & 16 & 459 & 145 \\
\hline Dichotomius (Luederwaldtinia) carbonarius (Mannerheim) & 1,123 & 68 & 80 \\
\hline Dichotomius (Luederwaldtinia) glaucus (Harold) & 0 & 35 & 17 \\
\hline Dichotomius melzeri (Luederwaldt) & 330 & 12 & 1 \\
\hline Dichotomius (Luederwaldtinia) nisus (Olivier) & 47 & 658 & 641 \\
\hline Dichotomius (Dichotomius) semianeus (Germar) & 11 & 46 & 14 \\
\hline Dichotomius (Selenocopris) ascanius piceus (Luederwaldt) & 1 & 0 & o \\
\hline Dichotomius (Dichotomius) sp. 1 & 0 & o & 1 \\
\hline Dichotomius (Selenocopris) ascanius (Harold) & 0 & 12 & o \\
\hline Digitonthophagus gazella (Fabricius) & 3 & 518 & 120 \\
\hline Eurysternus caribaeus (Herbst) & 1,548 & 35 & 30 \\
\hline Eurysternus parallelus Castelnau & 374 & 2 & 1 \\
\hline Genieridium bidens (Balthasar) & 1 & 2,371 & 283 \\
\hline Gromphas inermis Harold & o & o & 1 \\
\hline Isocopris inhiatus (Germar) & 0 & o & 3 \\
\hline Malagoniella (Megathopomima) puncticollis aeneicollis (Waterhouse) & 0 & 14 & o \\
\hline Ontherus digitatus Harold & 0 & 14 & 10 \\
\hline Ontherus sulcator (Fabricius) & 8 & 145 & 94 \\
\hline Ontherus appendiculatus (Mannerheim) & 13 & 2,183 & 391 \\
\hline Onthophagus catharinensis Paulian & 246 & 13 & o \\
\hline Onthophagus hirculus Mannerheim & 13 & 103 & 31 \\
\hline Onthophagus ptox Erichson & 115 & 470 & 124 \\
\hline Trichillum externepunctatum Preudhomme de Borre & 11 & 1,233 & 617 \\
\hline \multicolumn{4}{|l|}{ Hybosoridae, Hybsorinae } \\
\hline Coilodes humeralis (Mannerheim) & 28 & 0 & 0 \\
\hline Coilodes sp.1 & 104 & 2 & o \\
\hline Subtotal & 5,346 & 13,138 & 25,871 \\
\hline Total Species Richness (s) 53 & $\mathbf{S}=\mathbf{3 9}$ & $\mathbf{S}=\mathbf{3 9}$ & $\mathrm{S}=\mathbf{4 1}$ \\
\hline Total & \multicolumn{3}{|c|}{44,355} \\
\hline
\end{tabular}


vividus (Germar), Ateuchus sp.1, Canthidium viride (Lucas), Canthidium sp.1, Canthon laminatus Balthasar, Coprophanaeus jasius (Olivier), Coprophanaeus spitzi (Pessoa), Deltochilum (Deltohyboma) aspiricolle Bates, Dichotomius bos (Blanchard), Dichotomius (Luederwaldtinia) carbonarius, Dichotomius melzeri (Leuderwaldt), Dichotomius (Luederwaldtinia) nisus (Olivier), Dichotomius (Dichotomius) semianeus (Germar), Digitonthophagus gazella (Fabricius), E. caribaeus, Eurysternus (Eurysternus) parallelus Castelnau, Ontherus sulcator (Fabricius), O. appendiculatus, Onthophagus hirculus Mannerheim, Onthophagus ptox (Erichson), P. brasiliensis, and T. externepunctatum (Table 1).

Seven species were exclusive to the native semi-deciduous forest: Canthidium dispar (Harold), Canthidium (Eucanthidium) sp.2, Canthon (Canthon) virens chalybaeus Blanchard, Canthon (Glaphyrocanthon) oliverioi (Pereira \& Martínez), Canthon quinquemaculatus Castelnau, Coilodeshumeralis(Mannerheim), and Dichotomius (Selenocopris) ascanius piceus (Leuderwaldt); three species to the pasture: Canthon (Canthon) sp.2, Dichotomius (Selenocopris) ascanius (Harold), and Malagoniella (Megathopomima) puncticollis aeneicollis (Waterhouse), and five species occurred only in the agroecosystem: Canthidium sulcatum (Perty), Gromphas inermis Harold, Deltochilum (Hybomidium) icarus (Olivier), Dichotomius (Dichotomius) sp.1, and Isocopris inhiatus inhiatus (Germar) (Table 1).

The following seven species occurred concomitantly in both anthropized environments (i.e., pasture and agroecosystem): Blackburneus laxepunctatus (Schmidt), Aphodius (Nialus) nigritus Fabricius, A. sculptilis, Canthon (Francmonrosia) dives (Harold), Coprophanaeus (Metallophanaeus) sp. 1, Dichotomius (Luederwaldtinia) glaucus (Harold), and Ontherus digitatus Harold (Table 1).

The agroecosystem supported significantly higher abundance and species richness of dung beetles than the native forest or pasture (Table 2). In this research the occurrence of the most abundant and dominant species of dung beetles differed between the three environments (Table 2). In all environments, populations were higher in the periods with higher temperature and rainfall. The abundance of dung beetles had a strong positive correlation with precipitation $(\mathrm{r}=0.237, \mathrm{P}<0.01, \mathrm{~N}=391)$, and with the monthly average temperature $(\mathrm{r}=0.373, \mathrm{P}<0.01, \mathrm{~N}=391)$.
The months with the highest abundances of dung beetles, in descending order of abundance, were: Oct 2006 (14.94\%), Oct 2007 (14.57\%), Nov 2006 (8.58\%), and Dec 2006 (8.38\%), in the pasture; Dec 2006 (35.13\%), Dec 2007 (15.79\%), Nov 2006 (11.93\%), Dec 2005 (5.50\%), and Oct 2006 (5.09\%), in the agroecosystem, and Nov 2006 (15.22\%), Dec 2006 (13.65\%), Dec 2005 (11.78\%), and Oct 2007 (8.90\%), in the native forest (Figure 1).

In this study, the adults of the Scarabaeidae species with the following behaviors: endocoprid (i.e., digging galleries inside the cattle dung), paracoprid (i.e., burying portions of feces below the fecal mass), and telecoprid (i.e., burying portions of feces at a distance from the fecal mass), predominantly emerged in the late spring and early summer. They presented an increase in abundance during the seasons of higher rainfall and temperature (Figure 2).

Labarrus pseudolividus showed highest abundances in Nov 2005, Oct 2006, and Sep 2007. Ontherus appendiculatus was more abundant in the months of Feb and Oct 2006, and Mar and Oct 2007. In 2006, P. brasiliensis and T. externepunctatum had similar population outbreaks, with small increases in Jan, Feb, Oct, and Nov. Only P. brasiliensis had higher populations in Mar and Oct 2007, with low abundance in the remaining months during the 2 yrs evaluated (Figure 3). In the agroecosystem, the species $A$. platensis and $A$. sculptilis were collected all year, with high captures in Oct, Nov, and Dec in 2005, 2006, and 2007. Ataenius sculptilis also presented an increase in abundance in Mar 2006 (Figure 4). In the native forest, D. carbonarius presented higher populations in the months of Nov and Dec 2005 and 2006, Sep and Oct 2006, and Sep and Oct 2007. In this ecosystem, $D$. carbonarius was not captured in the months of Mar, Apr, May, Jun, Jul, or Aug. On the other hand, E. caribaeus occurred during the entire period of this study, having their major population peak in Oct (Figure 5).

\section{DISCUSSION}

In this research, in general, the abundance of 54 dung beetle taxa, were highest in summer (Oct, Nov, and Dec) (Table 1), overlapping with higher temperatures and rainfall. An early population increase occurred at the start of spring (Sep). In January, there was a population decline that continued until February (Figure 1). This population pattern may represent a reproductive strategy,

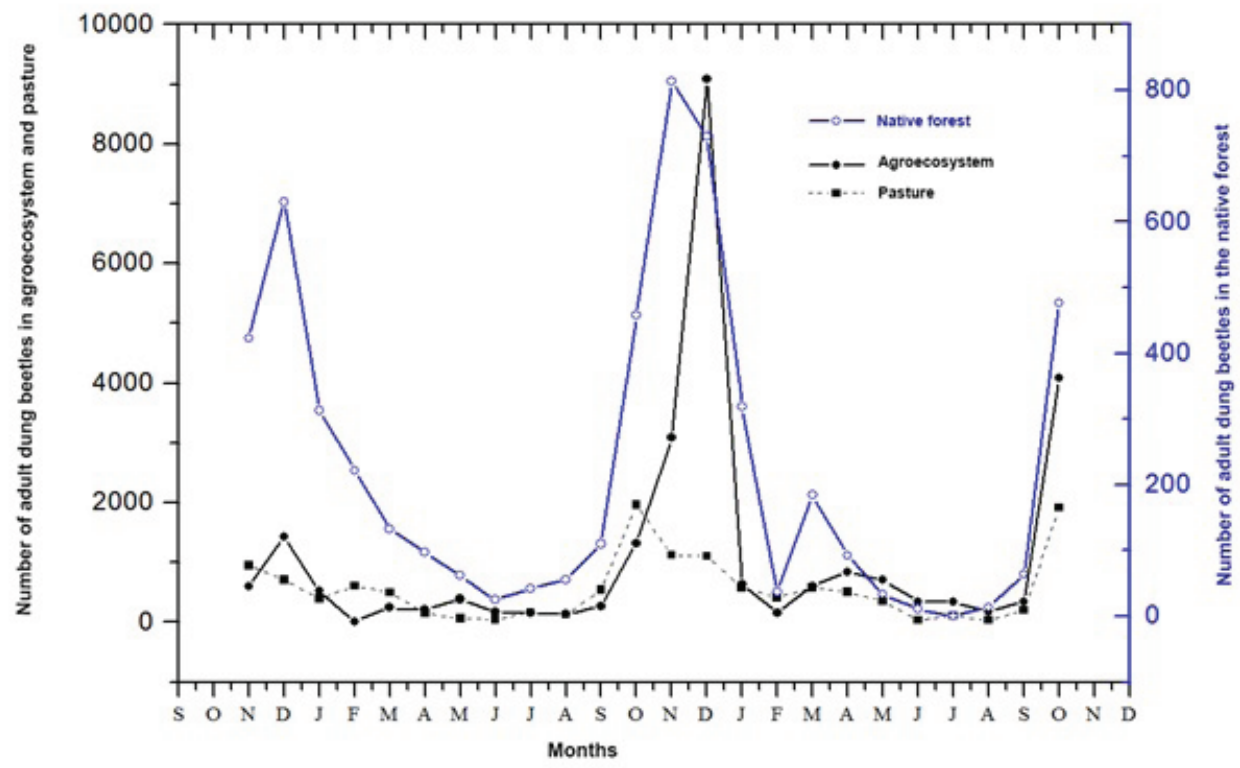

Figure 1. Abundance of coprophagous beetles (Coleoptera: Scarabaieidae) in three environments (i.e., native semi-deciduous forest, agroecosystem and pasture), and month of sampling in the municipality of Dourados, Mato Gosso do Sul state, Midwest Brazil (Nov 2005 to Nov 2007). 


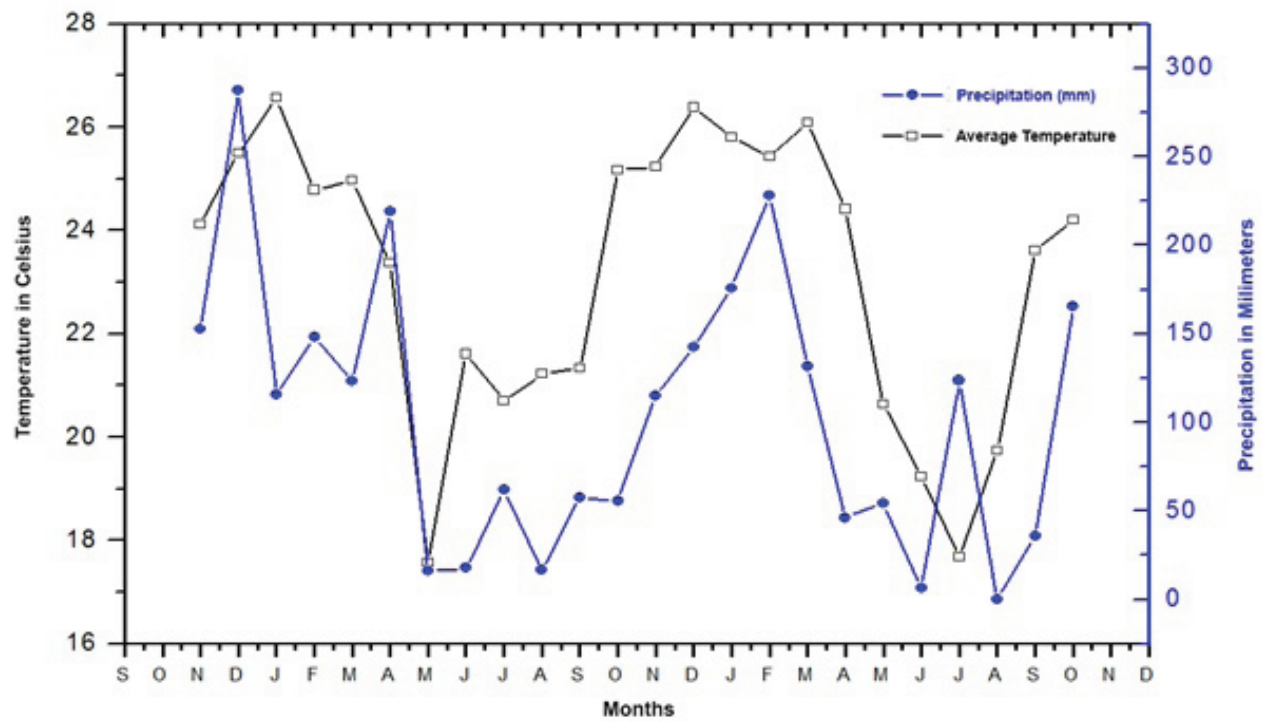

Figure 2. Average temperature $\left({ }^{\circ} \mathrm{C}\right)$, and rainfall or precipitation (mm) in the municipality of Dourados, Mato Gosso do Sul state, Midwest Brazil, from Nov 2005 to Nov 2007.

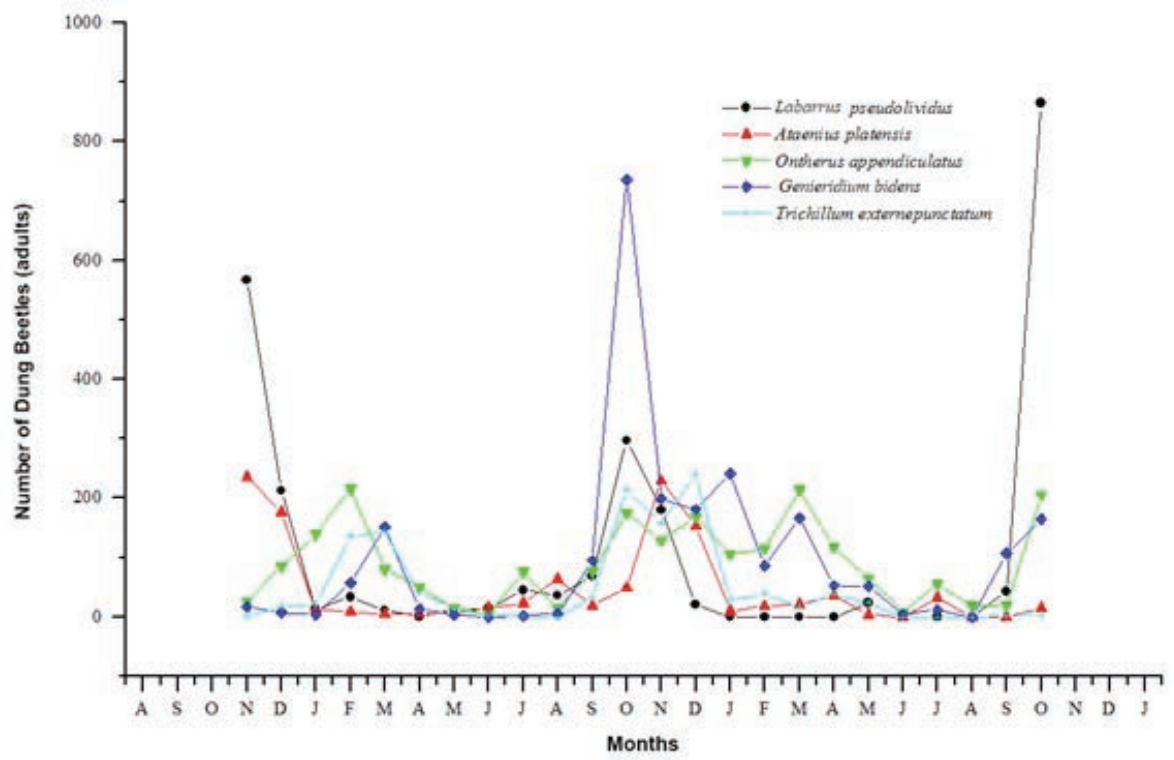

Figure 3. Population fluctuation of the top five most abundant dung beetle (Coleoptera: Scarabaeidae) species captured by month in pitfall traps in a pasture of signal grass, Urochloa decunbens, in the municipality of Dourados, Mato Gosso do Sul state, Midwest Brazil (Nov 2005 to Nov 2007)

especially for univoltine species, because in the summer higher precipitation makes the soil soft, facilitating synchronized adult emergence. This aspect was previously discussed by KolLer et al. (2007). Overall, our results show a strong correlation between the abundance of dung beetle species with increasing temperature and rainfall, indicating that, despite differences in land use, anthropized, (i.e., agricultural and grazing areas) or intact soil (i.e. forested environment), the correlation remains.

Disproving our hypothesis, the native semi-deciduous forest supported lower species richness of dung beetles, in comparison with the agroecosystem, and presented no significant difference with the pasture (Table 1 ).

B. laxepunctatus, formerly Aphodius (Blackburneus) laxepunctatus (cited in Rodrigues et al. 2013 as Aphodius (Blackburnium) lexepunctatus Schimidt (error), occurred in both anthropized environments (pasture and agrosystem). This species occurs in Argentina, Bolivia, Brazil, Costa Rica, French Guiana, Paraguay, Peru, Suriname, Venezuela (Dellacasa et al. 2011). G. inermis Harold (formerly G. lacordairei Blanchard), occurred only a single specimen in the agroecosystem. This species is reported from Argentina, Brazil, Bolivia, Paraguay and Uruguay (CuPELlo \& VAZ-DE-MeLlo 2013) (Table 1).

Herein, the average number of Scarabaeidae collected in the positive traps (i.e., traps that captured at least one individual) as well the mean number of adults in the positive traps in the semideciduous forest was significantly lower than the averages in the pasture or agricultural environments. On the other hand, there was no significant difference in the capture of adults between the agroecosystem or pasture environments (Table 2).

We found that the abundance and species richness of dung beetles varied among the sampled environments, except for $A$. platensis and $A$. sculptilis, which were highly abundant in both anthropized environments: pasture and agroecosystem (Table 2). This result shows that the dominance of a species is related to its adaptability to a particular environment. As discussed by Howden \& Nealis (1975), species of dung beetles have a close relationship with specific habitats. There are groups of dung beetle species adapted to open environments and others to 


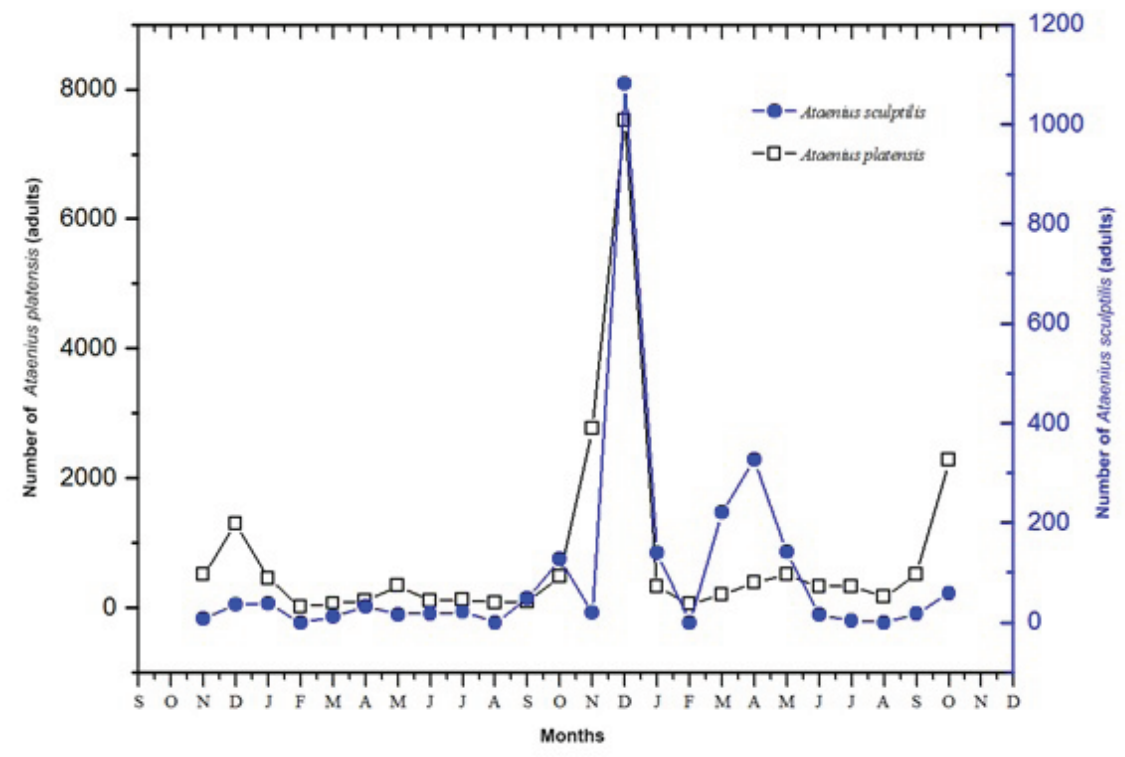

Figure 4. Population fluctuation of the top two most abundant dung beetle (Coleoptera: Scarabaeidae) species captured by month in pitfall traps in an agroecosystem in the municipality of Dourados, Mato Gosso do Sul state, Midwest Brazil (Nov 2005 to Nov 2007)

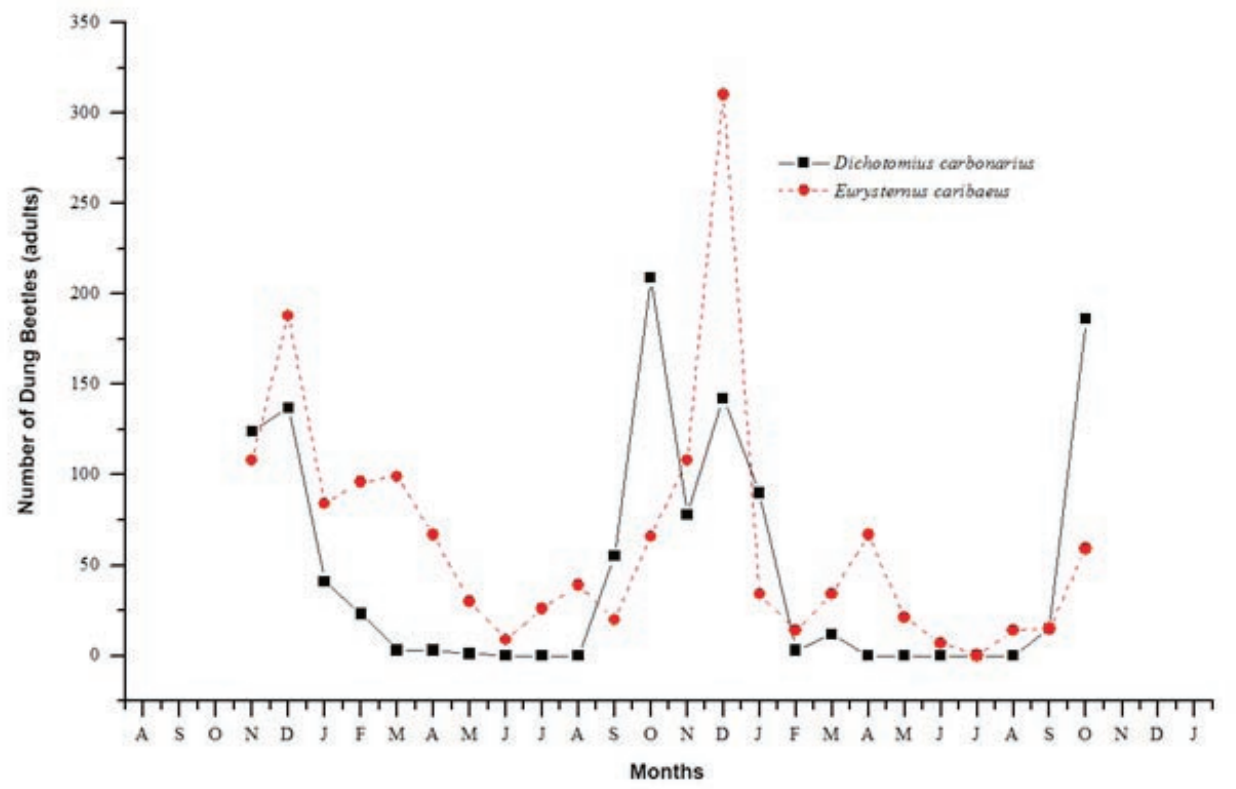

Figure 5. Population fluctuation of the top two most abundant dung beetle (Coleoptera: Scarabaeidae) species captured by month in pitfall traps in a semi-deciduous forest in the municipality of Dourados, Mato Gosso do Sul state, Midwest Brazil (Nov 2005 to Nov 2007)

Table 2. Number of dung beetle specimens caught in pitfall traps in 3 environments from the municipality of Dourados, Mato Grosso do Sul state, Midwest Brazil by weather variables and the type of environment (Nov 2005 to Nov 2007).

\begin{tabular}{|c|c|c|c|c|c|}
\hline \multirow{2}{*}{ Environment } & \multirow{2}{*}{\multicolumn{2}{|c|}{ Mean, (standard deviation), and (N) }} & \multicolumn{2}{|c|}{ Mann-Whitney } & \multirow{2}{*}{ Comparison } \\
\hline & & & $\mathrm{Z}$ & $\mathrm{P}$ & \\
\hline Temperature & $<25^{\circ} \mathrm{C}$ & $>25^{\circ} \mathrm{C}$ & & & \\
\hline Pasture & $20.58(24.06)(78)$ & $58.07(54.93)(60)$ & -5.966 & $<0.001$ & $a<b$ \\
\hline Agroecosystem & $23.96(36.03)(78)$ & $72.61(72.11)(49)$ & -4.912 & $<0.001$ & $\mathrm{a}<\mathrm{b}$ \\
\hline Semi-deciduous forest & $8.73(8.31)(71)$ & $34.96(28.28)(55)$ & -6.181 & $<0.001$ & $\mathrm{a}<\mathrm{b}$ \\
\hline Total & $18.04(26.50)(27)$ & $54.66(55.86)(164)$ & -9.623 & $<0.001$ & $\mathbf{a}<\mathbf{b}$ \\
\hline Precipitation & $<25 \mathrm{~mm}$ & $>25 \mathrm{~mm}$ & & & \\
\hline Pasture & $28.61(35.49)(84)$ & $49.74(53.39)(54)$ & -3.014 & 0.003 & $\mathrm{a}<\mathrm{b}$ \\
\hline Agroecosystem & $36.25(51.32)(88)$ & $57.36(68.74)(39)$ & -1.182 & 0.237 & ns \\
\hline Semi-deciduous forest & $18.68(19.08)(84)$ & $23.19(30.66)(42)$ & -0.093 & 0.926 & ns \\
\hline Total & $27.98(38.46)(256)$ & $43.68(54.37)(135)$ & -2.565 & 0.010 & $\mathbf{a}<\mathbf{b}$ \\
\hline
\end{tabular}

Comparison indicates significant differences by the Mann-Whitney U test, $\mathrm{p}<0.05$, ns $=$ not significant. Temperature: $\mathrm{a}<25^{\circ} \mathrm{C}, \mathrm{b}>25^{\circ} \mathrm{C}$, Precipitation: $\mathrm{a}<25 \mathrm{~mm}, \mathrm{~b}>25 \mathrm{~mm}$. 
forests. According to Howden \& NeALIs (1975), the abundance of dung beetles decreases in locations near deforested areas, where the sources of resources (animal feces) are suppressed as a result of vegetation removal. HERNÁNDEZ et al. (2003) reported that following an environmental disturbance, some species can explore the resources of substitution fauna (i.e., dung of small mammals and birds).

In this survey, a joint analysis of the 53 species collected (including two subspecies of Dichotomius) shows that there are greater abundance of adult dung beetles in the months with highest temperatures and rainfall, that occurs in Mato Grosso do Sul state from Oct to May (Figures 1-2). These results are in agreement with Flechtmann et al. (1995); Hilje (1996); Ronqui \& LOPES (2006) and KolLer et al. (2007), who all correlated the hottest and more humid months with the highest abundance of Scarabaeidae. These environmental conditions promote the acceleration of dung beetle metabolism and ensure greater flexibility of the soil, favoring the emergence of adults. However, in this study, the months of Jan and Feb 2007 were an exception: despite the high rainfall and high temperatures in the region, population levels were low.

In Feb 2006 and again in Feb 2007 in the agroecosystem, although there was relatively high rainfall and high temperatures, there was a decrease in the catch of the adults. This same pattern also was observed in the native forest, but the decrease was more pronounced from Dec to Feb 2007, with the population rising again in Mar (Figure 2). This fact can be attributed to the high occurrence of heavy rainfall during that season in the municipality of Dourados. As a consequence, soil flooding may have increased larval mortality. Another possibility is that the dung beetles were still in their larval stage at that time, with their emergence starting from Mar.

In the remaining months of the year, there was a low population level associated with lower precipitation and temperature. Apr, May, and Jun in 2006, and Jun and Aug in 2007, were the months with lower abundance of Scarabeiodea (Figure 1). In these seasons there was a rapid lowering of temperature and decreases in rainfall (Figure 2). Because of these weather conditions, the soil becomes dried and hardened, making it difficult for the adults to emerge. Additionally, according to NATion (2015), the decrease in temperature can cause lowering of biological reactions, decreasing the rate of larval development. Furthermore, adult reproduction can be impacted due to decreases in testicular and oogenesis activities, which in turn reduce oviposition.

The species L. pseudolividus, A. platensis, P. brasiliensis, and T. externepunctatum are multivoltine (FLECHTMANN et al. 1995) endocoprid dung beetles with a small body size (Doube 1990). In this study, these species were collected in almost all months in the pasture (Figure 3), being the predominant species for that ecosystem (Table 2). According to Nichols et al. (2007), dung beetles species with these characteristics, generally are hyperabundant in open areas. Higher abundance in the agroecosystem was due to the presence of $A$. platensis, with many adults caught in the rainy season, i.e., end of fall and all summer (Oct to Mar). Ataenius platensis was most abundant and frequent during the months of Nov 2005 and Nov 2006 (Figure 4).

The dung beetle species with a small body size showed high abundance in this study, however, they provide minimal burial of bovine dung, because they require only a small amount of resources to feed and breed. On the other hand, these small body sized beetles contribute to internal aeration of fecal masses, facilitating draining and disintegration, mainly in the dry season (winter), when other species are not active. These species of dung beetle (i.e., with endocoprid behavior) are not dependent on habitat soil type and according to Flechtmann \& Rodrigues (1995), are less affected by changes in weather.
Species such as D. carbonarius and $E$. caribaeus were frequently and constantly caught in the native semi-deciduous forest. Dichotomius carbonarius had higher abundance in Nov and Dec 2005 and 2006; Sep and Oct 2006, and Sep and Oct 2007. However, D. carbonarius was not captured in Mar, Apr, May, Jun, Jul, or Aug. On the other hand, E. caribaeus occurred throughout the entire $2 \mathrm{yr}$ period of this study, having a population outbreak in Oct (Figure 5). According to Flechtmann \& Rodrigues (1995) these two species are typical of forested ecosystems.

We found that for both univoltine species, with a long life cycle between 327-435 d, such as Coprophanaeus spitzi, Coprophanaeus (Metallophanaeus) sp.1, and G. inermis Harold, as well for multivoltine species, with a short life cycle of around $30 \mathrm{~d}$, such as A. platensis, C. dispar, $P$. brasiliensis, and $T$. externepunctatum, the highest abundance was more related to environmental factors, than to their own reproduction and development rates. Probably, the weather indirectly influences reproduction and development. Our results are consistent with other studies carried out in Brazil (Honer et al. 1987; FLeCHTMANN et al. 1995; RONQUI \& LOPES 2006; KOLLER et al. 2007; Novais et al. 2016). In South Africa, GASTON \& CHOwn (1999) concluded that the differences between dung beetles communities at altitude gradients are related to the weather differences between these environments. As reported by DAvis et al. (1999), there was a strong influence of biogeographic factors on the Scarabaeidae communities. They act most notably at the genus and species levels, being correlated with the type of weather, especially in tropical regions with seasonal rainfall and temperature variations.

In conclusion, there are a strong positive correlation between high temperature and rainfall with an increase in abundance of dung beetles (Scarabaeidae). There are differences in the patterns of abundance of the dung beetle communities between the environments (native semi-deciduous forest, pasture and agroecosystem). Scarabaeids were most abundant and with highest species richness in the agroecosystem ( 41 species); with no significant differences between the native semi-deciduous forest and pasture, with 39 species in each environment.

\section{ACKNOWLEDGMENTS}

We thank Mrs. João Fernandes, Paulo Luciano de Souza, and Ajurycaba Cortez de Lucena, who allowed the survey to occur on their properties. We acknowledge our funders, CNPqConselho Nacional de Desenvolvimento Científico e Tecnológico (Process: 305112/2012-0) based on research productivity to MA Uchoa, and Fundação de Apoio ao Desenvolvimento do Ensino, Ciência e Tecnologia do Estado de Mato Grosso do Sul (FUNDECT), and Coordenação de Aperfeiçoamento de Pessoal de Nível Superior (CAPES): FUNDECT-CAPES-PAPOS-MS 44/2014, and FUNDECT-CAPES 12/2015-BIOTA-MS-Ciência e Biodiversidade, for financial support.

\section{REFERENCES}

Bornemissza, G.F., 1976. The Australian dung beetle project 1965-75. Australian Meat Research Committee Review, 30: $1-30$.

Cupello, M. \& F.Z. Vaz-De-Mello, 2013.Taxonomic revision of the South American dung beetle genus Gromphas Brullé, 1837 (Coleoptera: Scarabaeidae: Scarabaeinae: Phanaeini: Gromphadina). Zootaxa, 3722: 439-482. DOI: https://doi.org/10.11646/zootaxa.3722.4.2.

Davis, A. L. V., C.H. Scholtz, \& L.C.D. Chown, 1999. Species turnover, community boundaries and biogeographical composition of dung beetle assemblages across an altitudinal gradient in South Africa. Journal of Biogeography, 26: 1039-1055. DOI: https://doi.org/10.1046/j.13652699.1999.00335.x. 
Dellacasa, M., G. Dellacasa \& R.D. Gordon, 2011. Systematic revision of the American taxa belonging to the Genera Alloblackburneus Bordat, 2009, and Blackburneus Schmidt, 1913, with description of seven new species (Coleoptera: Scarabaeidae: Aphodiinae). Insecta Mundi, 204: 1-52.

Doube, B.M., 1990. A functional classification for analysis of the structure of dung beetles assemblages. Ecological Entomology, 15: 371-383. DOI: https://doi.org/10.1111/j.1365-2311.1990. tboo820.x.

Flechtmann, C.A.H. \& S.R. Rodrigues, 1995. Insetos fimícolas associados a fezes bovinas em Jaraguá do Sul/SC. 1. Besouros Coprófagos (Coleoptera: Scarabaeidade). Revista Brasileira de Entomologia, 39: 303-309.

Flechtmann, C.A.H., S.R. Rodrigues \& H.T.Z. Couto, 1995. Controle biológico da mosca-dos-chifres (Haematobia irritans) em Selvíria, Mato Grosso do Sul. Revista Brasileira de Entomologia, 39: 259-276.

Gaston, K.J. \& S. L. Chown, 1999. Elevation and climatic tolerance: a test using dung beetles. Oikos, 86: 584-590. DOI: https://doi.org/10.2307/3546663.

Halffter, G., M. E. Favila \& V. Halfftar, 1992. A comparative study of the structure of the scarab guild in Mexican tropical rain forests and derived ecosystems. Folia Entomologica Mexicana, 84: 131-156.

Hernández, B., J.M. Maes, C.A. Harvey, S. Vílchez, A. Medina \& D. Sánchez, 2003. Abundancia y diversidad de escarabajos coprófagos y mariposas diurnas em um paisaje ganadero em el Departamento de Rivas, Nicaragua. Agroforesteria em las Americas, 10: 39-40.

Hilje, L., 1996. Estacionalidad de adultos de Scarabaeidea (Coleoptera) em Barva, Costa Rica. Revista de Biologia Tropical, 44: 719-729.

Honer, M.R., I. Bianchin \& A. Gomes, 1987. Desenvolvimento de um programa integrado de controle dos nematódeos e da mosca dos chifres na Região dos Cerrados: Campo Grande, Empresa Brasileira de Pesquisa Agropecuária (EMBRAPA) Centro Nacional de Pesquisa de Gado de Corte (CNPGC). 19 p.

Howden, H.F. \& V.G. Nealis, 1975. Effects of clearing in a tropical rain forest on the composition of coprophagus scarab beetle fauna (Coleoptera). Biotropica, 7: 77-83. DOI: https://doi.org/10.2307/2989750.

Koller, W.W., A. Gomes, S.R. Rodrigues \& P.F.I. Goiozo, 2007. Scarabaeidae e Aphodiidae coprófagos em pastagem cultivadas em área do cerrado Sul-mato-grossense. Revista Brasileira de Zoociência, 9: 81-93.
Losey, J.E. \& M. Vaughan, 2006. The economic value of ecological services provided by insects. BioScience, 56: 311-323. DOI: https://doi.org/10.1641/00063568(2006)56[311:tevoes]2.0.c0;2.

Nation, J.L., 2015. Insect Physiology and Biochemistry. $3^{\text {rd }}$ edition. CRC press, London, UK. 690 p.

Nichols, E., T. Larsen, S. Spector, A.L. Davis, F. Escobar, M. Favila \& K. Vulinec, 2007. Global dung beetle response to tropical forest modification and fragmentation: a quantitative literature review and meta-analysis. Biological Conservation, 137: 1-19. DOI: https://doi.org/10.1016/j. biocon.2007.01.023.

Novais, S M.A., L.A. Evangelista, J. Reis-Júnior \& F.S. Neves, 2016. How does dung beetles (Coleoptera: Scarabaeidae) diversity vary along a rainy season in a tropical dry forest? Journal of Insect Science, 16: 1-6. DOI: https://doi.org/10.1093/jisesa/ iew069.

Primo, A.T., 1992. El ganado bovino iberico en las Americas: 500 años despues. Archivos de Zootecnia, 41: 421-432.

Projeto RadamBrasil, 1982. Folha SF. 21 Campo Grande: geologia, geomorfologia, pedologia, vegetação e uso potencial da terra. Ministério das Minas e Energia, Secretaria Geral, Brazil. 416 p.

Rodrigues, M.M, M.A. Uchoa \& S. Ide, 2013. Dung beetles (Coleoptera: Scarabaeoidea) in three landscapes in Mato Grosso do Sul, Brazil. Brazilian Journal of Biology, 73: 211-220. DOI: https://doi.org/10.1590/s1519-69842013000100023.

Ronqui, D.C. \& J. Lopes, 2006. Composição e diversidade de Scarabaeoidea (Coleoptera) atraídas por armadilhas de luz em área rural no norte do Paraná, Brasil. Iheringia: Série Zoologica, 96: 103-108. DOI: https://doi.org/10.1590/s007347212006000100018.

Silva, F.A.B., M.I.M. Hernández, S. Ide \& R.C. Moura, 2007. Comunidade de escarabeíneos (Coleoptera: Scarabaeidae) copro-necrófagos da região de Brejo Novo, Caruaru, Pernambuco, Brasil. Revista Brasileira de Entomologia, 51: 228-233. DOI: https://doi.org/10.1590/s008556262007000200014 .

Whittaker, R.H., 1972. Evolution and measurement of species diversity. Taxon 21: 213-251. DOI: https://doi.org/10.2307/1218190.

\section{Suggestion citation:}

Uchoa, M.A., M.M. Rodrigues, 2019. Dung beetles (Coleoptera: Scarabaeoidea) population patterns in three environments in the Midwest of Brazil. EntomoBrasilis, 12 (1): 19-26.

Available on: $\underline{\text { doi:10.12741/ebrasilis.v12i1.825 }}$
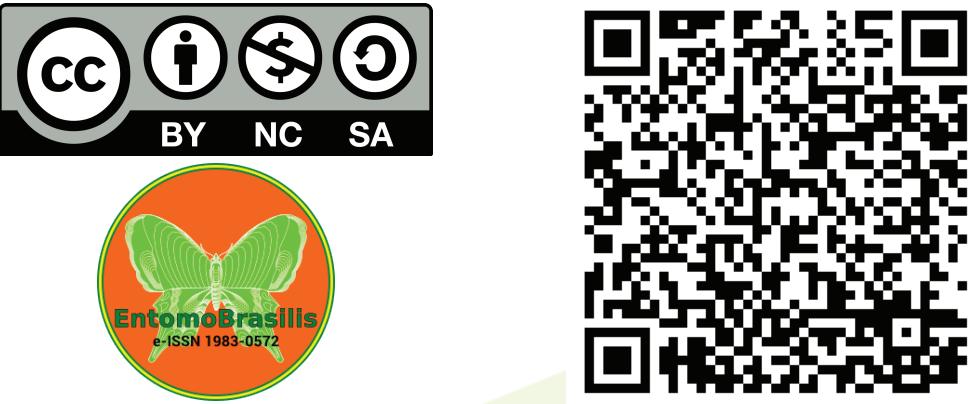